\title{
ONECUT2 Gene
}

National Cancer Institute

\section{Source}

National Cancer Institute. ONECUT2 Gene. NCI Thesaurus. Code C157288.

This gene is involved in the transcriptional activation of genes affecting melanocyte and hepatocyte differentiation. 